\title{
Effects of Foliar Fertilizations in the Vitis vinifera L. Species
}

\author{
Amelot Grori $^{1 *}$, Ariola Bici ${ }^{2}$, Renata Kongoli ${ }^{3}$ and Edlira Kukali ${ }^{3}$ \\ ${ }^{1}$ Faculty of Agricultural \& Environment, Agricultural University of Tirana \& Faculty of \\ Agricultural \& Environment, Agricultural University of Tirana, Albania \\ ${ }^{2}$ Economy Faculty of Science, University of Tirana, Albania \\ ${ }^{3}$ Faculty of Food Biotechnology, Agricultural University of Tirana, Albania \\ *Corresponding author
}

\section{A B S T R A C T}

\begin{tabular}{l} 
Ke y w o r d s \\
$\begin{array}{l}\text { Fertilization, Iron, } \\
\text { Magnesium, } \\
\text { Potassium, Vitis } \\
\text { vinifera L., Zinc }\end{array}$ \\
\hline Article Info \\
$\begin{array}{l}\text { Accepted: } \\
\text { 17 January } 2018 \\
\text { Available Online: } \\
\text { 10 February } 2018\end{array}$ \\
\hline
\end{tabular}

Nutrition in the grapevine is a specific agrotechnical measure affecting the quantity and quality of grape production and its products. Proper nutrition has a great influence on the many biochemical and physiological processes that happen in various grapevine organs. Among the macro-elements, potassium has a very important role in the development of the vital processes of the vine. This element has the most important influence on maturation processes and increases the resistance of the vine to low winter temperatures. Results achieved in a 2-year (2016-17) study with seven different pleural treatments (along with the control) showed that fertilization with $\mathrm{K}$ reduced $\mathrm{Mg}$ almost half compared to untreated vineyards, resulting in chlorosis in the basal leaves. High $\mathrm{K} / \mathrm{Mg}$ Report, determining the low absorption of $\mathrm{Mg}$, did not sit on our test as from leafy fertilization as from irrigation and fertilization both (injection with drop irrigation) with $\mathrm{MgSO}_{4}$ solution. On the other hand, the application of Mg except Fe supply had the same effect on the absorption of $\mathrm{Zn}$ soils and its accumulation in leaves and leaf tails. For more, foliar fertilization with Fe has increased Fe levels on leaves, on berry and on one measure smaller in ripening too.

\section{Introduction}

All plants need an adequate supply of macroand micro-elements in order to comply with their normal physiological and biochemical functions. In addition to basic nutritional mineral resources (nitrogen, phosphorus and potassium), some other elements (magnesium, iron, zinc, boron, etc.) are considered essential for the metabolic processes of plants, because they are coofactor and/or activators of many metabolic enzymes, 1992 (Lindsay Allen and
Bruno de Benoist, 2006). Nutrients mentioned above are necessary for life cycle of the vine, from the initiation of bud to leaf fall, and generally restrict production of grape vineyards in the world (Kummer and Vasconcelos, 2001).

The application of nutrients contributes to the manipulation of environmental variables when properly integrated into a land management program (Omar Dary, 1968). It can also be used as a supplement to compensate for the 
deficiencies of the earth: to provide sufficient nutrients when nature is not supplying them during critical stages of seasonal growth cycle (George and Rice, 2016).

However, despite the obvious importance of soil composting in the growth and production of plants, knowledge and understanding about the availability of the nutrient, the actual absorption of different fertilizers and how they affect the vineyard physiology and productivity is not well known by farmers (Bergmann, 1992).

\section{Materials and Methods}

\section{Location, grapevine material and experimental set up}

The experiment was conducted in a vineyard plant in Sauk, Tirana; the methodology was applied foliar fertilization on of grapevine Cv. "Shesh $i$ Zi". From meteorological data (Figure 1) that are recorded in a meteorological station located in Petrele, Tirana, near the center of the experiment, the annual precipitation was $917-1197 \mathrm{~mm}$ in 2016 and 2017 respectively. In addition, it was noted that large differences in temperature between these two years. During the growth cycle, the temperature range was more or less the same during the summer months, with lower temperatures in April, May and September 2016 compared to next year.

After planting, the grapevines were periodically sprayed with treatments in order to avoid diseases, following a suitable wintering protocol for kleistotecs of fungi, based on integrated rules of pest management. It also created an irrigation system, which uses water to avoid drought conditions in the summer time.

Physical and chemical parameters of the soil are shown in (Table 1) (analysis carried out by the laboratory; "Another vision, Elbasan, Albania").

In the years 2016- 2017 after short pruning, was held with 4 buds per shoots, some experimental rows of grape, planted on plots, was apply Foliar fertiligation, in the two years, 5 treatments, with 3 repetitions per each 4 plants "Shesh i Zi" (Table 2).

Five variants of foliar fertilization were conducted compared to a row of grape that was not applied deciduous.

The quantities of fertilizers extensions $(50 \mathrm{~N}$, $90 \mathrm{P}_{2} \mathrm{O}_{5}$ and $140 \mathrm{~K}_{2} \mathrm{O}$ in $\mathrm{kg} / \mathrm{ha}$ ) was concluded from the terrein object analysis $\left(20 \mathrm{mg} \mathrm{kg}^{-1}\right.$ amonlaktozës $\mathrm{AL} ; \mathrm{P}_{2} \mathrm{O}_{5}$ soluble and $100 \mathrm{mg}$ $\mathrm{kg}^{-1} \mathrm{AL}-\mathrm{K}_{2} \mathrm{O}$, as results of consultation of "Other Vision Laboratory Elbasan) and recommendations of the annual cover (E. Kukali). Fertigation was used as ammonium sulphate $(20.6 \% \mathrm{~N})$ in two years in the spring, while phosphorus as phosphate $\left(26 \% \mathrm{P}_{2} \mathrm{O}_{5}\right)$ and potassium as potassium sulphate $(50 \%$ $\mathrm{K}_{2} \mathrm{O}$ ) was applied only in 2016 (Diaz et al., 2010). Fertilizers containing: $\mathrm{Mg}$ Bittersalz "( $\mathrm{MgSO}_{4}$ x $7 \mathrm{H}_{2} \mathrm{O}, 16 \% \mathrm{MgO}$, Germany), Fe (Fe comprising aminacide, 5\% (w/v) Fe), are added before flowering in May, individually or combinationed (Edlira Kukali, 2009). Application of $\mathrm{Mg}$ or $\mathrm{Fe}$ is calculated based on the recommendations. In order to understand the efficacy of $\mathrm{Mg}$ and $\mathrm{Fe}$ in the soil application was combined with foliar fertilizations and was compared with untreated variant (control) (George and Rice, 2016).

\section{Analysis of minerals in leaves and measurements}

The leaf analysis is done by selecting eight to twelve leaves of recurrence (2-3 x vine leaves on each plant). After sampling, leaf surfaces are separated from the leaf stems, which are washed with tap water running initially and 
then with deionizer water in order to remove dust and other waste in the leaf surface; then leaves/stems are dried in the oven at $105^{\circ} \mathrm{C}$ for three days. After homogenization and grinding $\left(28 \mathrm{~Hz} \mathrm{~s}^{-1}, 2.30 \mathrm{~min}\right.$; emulsifier MM 400) of the leaf surface $(0.5 \mathrm{~g})$ and the stalk $(0.3 \mathrm{~g})$ are dissolved in $\mathrm{HNO}_{3}$ (covered with lids) and $\mathrm{H}_{2} \mathrm{O}_{2}$ (65\% and $30 \%$, respectively) in PTFE furnace in a sand bath (Edlira Kukali, 2009).

The dry residue was re-dissolved in $0.5 \mathrm{ml}$ of $\mathrm{HNO}_{3}$ 1-2 min heating and filling a final volume of $25 \mathrm{ml}$ with deionizer water. Mineral concentrations were determined by spectrophotometer (SPECTRAA-55), in "Another Vision Laboratory, Elbasan" Standards in the following wavelength: $\mathrm{nm}$, $766.5(\mathrm{C}), 285.2(\mathrm{Mg}), 248.3(\mathrm{Fe})$ and 213.9 square $\mathrm{Zn}$ ). For each set of measurements were carried out appropriate quality controls (standard reference materials (SRMs) from the National Institute of Standards and Technology - NIST- Italy (Parsons et al., 1983).

\section{Statistical analysis}

All experimental data were analyzed by ANOVA using SPSS statistical package. Where changes in the ANOVA were significant for $(\mathrm{p}<0: 05)$ (Ruben Geert van den Berg, 2017)

\section{Results and Discussion}

\section{$\mathrm{K}$ and $\mathrm{Mg}$ concentration in leaves of the vine}

The grapevines which are newly initiated berries, the $\mathrm{K}$ concentration in the untreated grapevines was $1.0 \pm 0.1$ versus $1.2 \pm 0.3 \%$ in the leaf surface and $2.6 \pm 0.3$ versus $2.7 \pm$ $0.5 \%$ in the shoots in 2016 and 2017 respectively (Figure 2). The measured concentration of $\mathrm{K}$ was quite similar in the ripening process, being $1.0 \pm 1.3$ vs. 0:04 \pm
$0.2 \%$ in the leaf surfaces and $2.4 \pm 0.3$ versus $2.9 \pm 0.5 \%$ at the shoots, in the same years respectively. Treatments (2-8) with the addition of $\mathrm{K}$ showed higher concentrations of $\mathrm{K}$ compared to the untreated grapevines both in times of sampling and in both years. In general average, the $\mathrm{K}$ concentration was increased by 1-6 fold in all samples treated compared with untreated those of grapevines. In contrast, the $\mathrm{Mg}$ concentration was significantly higher (Figure 2) in samples of untreated grape leaves in two years and both times the sampling. In the initiation phase of berry, measuring the concentration of $\mathrm{Mg}$ it was 0:08 \pm 0:02 vs. 0:10 $\pm 0.01 \%$ sip. gjethore and $0: 19 \pm 0: 02$ vs. $0: 14 \pm 0.01 \%$ spring in 2016 and 2017, respectively.

Furthermore, $\mathrm{Mg}$ content in two stages, the leaves of untreated grape averaged almost twice (1.9-fold) higher than the additional treatments with $\mathrm{K}$ (average value against $0.0780 .101 \%$ in $0063-0073$ leaf surface and $0: 11$ to $00: 15 \%$ in shoots 2016 to 2017 respectively) In the control grapevines, the $\mathrm{Mg}$ concentration was increased by 1.6-fold (average of two years) from the collected berries for ripening in two stages on leaf surfaces $(0: 14 \pm 0: 01$ vs. $0: 14 \pm 0.02 \%$ in 2016 and 2017 respectively) and shoots (0:26 \pm 0:02 0:27 Against $\pm 0.02 \%$, respectively). A comparable improvement was also seen in the shootses treated with $\mathrm{Mg}$ and Fe fertilizers (4, 6-8) in 2017 (Table 3).

\section{Effects of different fertilizer treatments on the concentration of $\mathrm{Fe}$ and $\mathrm{Zn}$ in the leaves of grape}

In initiating of berries 2016, the content of Fe was much higher than the ripening time of the same year and both times the sampling in later (average values ranging between 201 and 264 $\mathrm{mg} \mathrm{kg}^{-1}$ in treatments 5 and 6 even $>300 \mathrm{mg}$ $\mathrm{kg}^{-1}$ in the leaf surface, and $41-63 \mathrm{mg} \mathrm{kg}^{-1}$ in shoots (Figure 3). 
Table.1 The average physical and chemical characteristics of the soil (Taulant Mitrushi)

\begin{tabular}{|c|c|}
\hline Parameters & $\begin{array}{l}\text { A verage } \\
\text { value }\end{array}$ \\
\hline pH (in water) $1: 1.25$ ) & 8.0 \\
\hline$E C\left(d_{S ~ m}^{-1}\right)$ & 0.80 \\
\hline OM (\%) & 1.9 \\
\hline CEC $\left(\mathrm{cmol} \mathrm{kg}^{-1}\right)$ & 24.9 \\
\hline Total $\mathrm{CaCO}$ & 33.0 \\
\hline Active Lym (\%) & 9.0 \\
\hline Total N (mg kg $\left.{ }^{-1}\right)$ & 1039 \\
\hline Available $\mathbf{P}\left(\mathrm{mg} \mathrm{kg}^{-1}\right)$ & 8 \\
\hline $\mathrm{K}$ available ( $\mathrm{mg} \mathrm{kg}^{-1}$ ) & 174 \\
\hline$S$ available $\left(\mathrm{mg} \mathrm{kg}^{-1}\right)$ & 4 \\
\hline
\end{tabular}

\begin{tabular}{|l|l|}
\hline Available $\mathrm{Ca}\left(\mathrm{mg} \mathrm{kg}^{-1}\right)$ & 4793 \\
\hline A vailable $\mathrm{Mg}\left(\mathrm{mg} \mathrm{kg}^{-1}\right)$ & 43 \\
\hline B A vailable $\left(\mathrm{mg} \mathrm{kg}^{-1}\right)$ & $1: 34$ \\
\hline A vailable $\mathrm{Cu}\left(\mathrm{mg} \mathrm{kg}^{-1}\right)$ & 17.5 \\
\hline available $\mathrm{Fe}\left(\mathrm{mg} \mathrm{kg}^{-1}\right)$ & 143 \\
\hline A vailable $\mathrm{Mn}\left(\mathrm{mg} \mathrm{kg}^{-1}\right)$ & 104 \\
\hline Mo available $\left(\mathrm{mg} \mathrm{kg}^{-1}\right)$ & $12: 05$ \\
\hline A vailable $\mathrm{Zn}\left(\mathrm{mg} \mathrm{kg}^{-1}\right)$ & 3.9 \\
\hline Clay (\%) & 32.7 \\
\hline Lym (\%) & 47.2 \\
\hline Sand $(\%)$ & 20.1 \\
\hline texture & Sandy clay \\
\hline
\end{tabular}

Table.2 Description of treatments applied in the roots of experimental vineyards "Sheshi i Zi, Sauk, Tirana"

\begin{tabular}{|c|c|c|}
\hline No & Treatment & $\begin{array}{l}\text { Concentration/quantity of foliar } \\
\text { fertilization }\end{array}$ \\
\hline 1 & Control (without treatment) & Didn't treat with supplement feed \\
\hline 2 & NPK & $\begin{array}{l}10 \mathrm{~g} \mathrm{~N} .18 \mathrm{~g} \mathrm{P}_{2} \mathrm{O}_{5} \text { and } 28 \mathrm{~g} \mathrm{~K}_{2} \mathrm{O} \\
\text { per root }\end{array}$ \\
\hline 3 & $\mathrm{NPK}+\mathrm{Mg} \mathrm{L}$ & $\begin{array}{l}3 \%(2 \mathrm{w} / \mathrm{v}) \text { Bittersalz" (foliar } \\
\text { fertilization) }\end{array}$ \\
\hline 4 & $\mathrm{NPK}+\mathrm{Mg} \mathrm{S}$ & $3 \%(\mathrm{w} / \mathrm{v})$ "Bittersalz" (fertigation) \\
\hline 5 & $\mathrm{NPK}+\mathrm{Fe} \mathrm{L}$ & $\begin{array}{l}0.15 \%(w / v) \text { "Foliacon } \mathrm{Fe} \text { " (foliar } \\
\text { fertilization) }\end{array}$ \\
\hline 6 & $\mathrm{NPK}+\mathrm{Fe} \mathrm{S}$ & $\begin{array}{l}0.15 \%(w / v) \\
\text { (fertigation) }\end{array} \quad$ "Foliacion $\quad F e "$ \\
\hline
\end{tabular}


Table. $3 \mathrm{~K} \%$ measured in the phase of the color change in ripening

\begin{tabular}{|l|l|l|l|l|}
\hline Treatments & $\mathbf{2 0 1 6}$ & & $\mathbf{2 0 1 7}$ & \\
& Leaf area & shoots & Leaf area & shoots \\
\hline 1 control & $0: 04$ & 0.3 & 0.2 & 0.5 \\
\hline 2 - NPK & 1 & 2.4 & 1.3 & 2.9 \\
\hline 3- NPK + Mg L & 1.1 & 2.3 & 1.2 & 2.8 \\
\hline 4- NPK + Mg S & 1.4 & 2.9 & 1.4 & 2.6 \\
\hline 5- NPK + Fe L & 1.2 & 2.7 & 1.5 & 2.3 \\
\hline 6- NPK + Fe S & 1.6 & 2.6 & 1.7 & 2.6 \\
\hline
\end{tabular}

Table.4 Percentage (\%) of $\mathrm{Mg}$, measured in the phase of berries initiating and in the phase of the color change (Ripening) 2016-2017

\begin{tabular}{|c|c|c|c|c|c|c|c|c|}
\hline \multirow[t]{3}{*}{ Treatments } & \multicolumn{4}{|l|}{2016} & \multicolumn{4}{|l|}{2017} \\
\hline & \multicolumn{2}{|l|}{ Leaf area } & \multicolumn{2}{|l|}{ Shoots } & \multicolumn{2}{|l|}{ Leaf area } & \multicolumn{2}{|l|}{ Shoots } \\
\hline & $\begin{array}{l}\text { initiation } \\
\text { of berry }\end{array}$ & Verasion & $\begin{array}{l}\text { initiation } \\
\text { of berry }\end{array}$ & Verasion & $\begin{array}{l}\text { initiation } \\
\text { of berry }\end{array}$ & Verasion & $\begin{array}{l}\text { initiation } \\
\text { of berry }\end{array}$ & Verasion \\
\hline 1 Control & 0.03 & 0.14 & 0.2 & 2.6 & 0.10 & 0.15 & 0.16 & 0.27 \\
\hline 2 - NPK & 0.08 & 0.15 & 0.03 & 0.16 & 0.02 & 0.19 & 0.03 & 0.28 \\
\hline 3- NPK + Mg L & 0.07 & 0.18 & 0.02 & 0.01 & 0.01 & 0.01 & 0.01 & 0.01 \\
\hline 4- NPK + Mg S & 0.06 & 0.01 & 0.19 & 0.02 & 0.02 & 0.02 & 0.02 & 0.02 \\
\hline 5- NPK + Fe L & 0.04 & 0.19 & 0.01 & 0.02 & 0.01 & 0.18 & 0.18 & 0.29 \\
\hline 6- NPK + Fe S & 0.05 & 0.02 & 0.02 & 0.03 & 0.01 & 0.03 & 0.03 & 0.02 \\
\hline
\end{tabular}

Table.5 Effects of different fertilizer treatments on the concentration of $\mathrm{Fe}$ and $\mathrm{Zn}$ in the leaves of grape

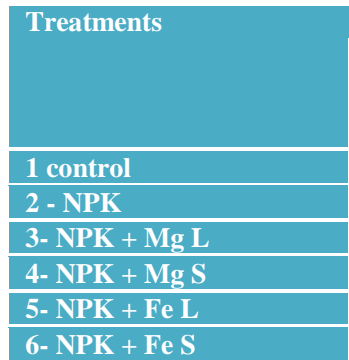

\begin{tabular}{|c|c|c|c|}
\hline \multicolumn{4}{|l|}{2016} \\
\hline \multicolumn{2}{|l|}{ Leaf area } & \multicolumn{2}{|l|}{ Shoots } \\
\hline $\begin{array}{l}\text { initiation of } \\
\text { berry }\end{array}$ & ripening & initiation of berry & ripening \\
\hline 87 & 78 & 81 & 83 \\
\hline 201 & 167 & 163 & 167 \\
\hline 264 & 160 & 177 & 166 \\
\hline 280 & 169 & 168 & 169 \\
\hline 271 & 209 & 204 & 209 \\
\hline 279 & 213 & 209 & 213 \\
\hline
\end{tabular}

\begin{tabular}{|c|c|c|c|}
\hline \multicolumn{4}{|l|}{2017} \\
\hline \multicolumn{2}{|l|}{ Leaf area } & \multicolumn{2}{|l|}{ Shoots } \\
\hline $\begin{array}{l}\text { initiation of } \\
\text { berry }\end{array}$ & ripening & $\begin{array}{l}\text { initiation of } \\
\text { berry }\end{array}$ & ripening \\
\hline 56 & 59 & 24 & 23 \\
\hline 68 & 69 & 33 & 27 \\
\hline 87 & 110 & 107 & 116 \\
\hline 106 & 112 & 123 & 125 \\
\hline 120 & 127 & 156 & 179 \\
\hline 279 & 213 & 139 & 144 \\
\hline
\end{tabular}

Table. $6 \% \mathrm{Zn}$ data in the phase of berries and initiating the phase of the color change in Ripening

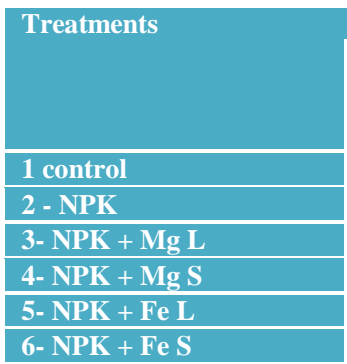

\begin{tabular}{|c|c|c|c|}
\hline \multicolumn{4}{|l|}{2016} \\
\hline \multicolumn{2}{|l|}{ Leaf area } & \multicolumn{2}{|l|}{ Shoots } \\
\hline $\begin{array}{l}\text { initiation of } \\
\text { berry }\end{array}$ & ripening & initiation of berry & ripening \\
\hline 17 & 14 & 27 & 52 \\
\hline 18 & 15 & 29 & 54 \\
\hline 19 & 15 & 30 & 54 \\
\hline 19 & 15 & 31 & 56 \\
\hline 19 & 16 & 32 & 55 \\
\hline 23 & 18 & 32 & 58 \\
\hline
\end{tabular}

\begin{tabular}{|c|c|c|c|}
\hline \multicolumn{4}{|l|}{2017} \\
\hline \multicolumn{2}{|l|}{ Leaf area } & \multicolumn{2}{|l|}{ Shoots } \\
\hline $\begin{array}{l}\text { initiation of } \\
\text { berry }\end{array}$ & ripening & $\begin{array}{l}\text { initiation of } \\
\text { berry }\end{array}$ & ripening \\
\hline 19 & 22 & 25 & 32 \\
\hline 21 & 23 & 26 & 34 \\
\hline 21 & 26 & 29 & 37 \\
\hline 23 & 24 & 27 & 36 \\
\hline 24 & 25 & 30 & 35 \\
\hline 23 & 26 & 25 & 36 \\
\hline
\end{tabular}


Fig.1 Distribution of monthly precipitation and average temperatures in 2016 and 2017, meteorological station, Tirana

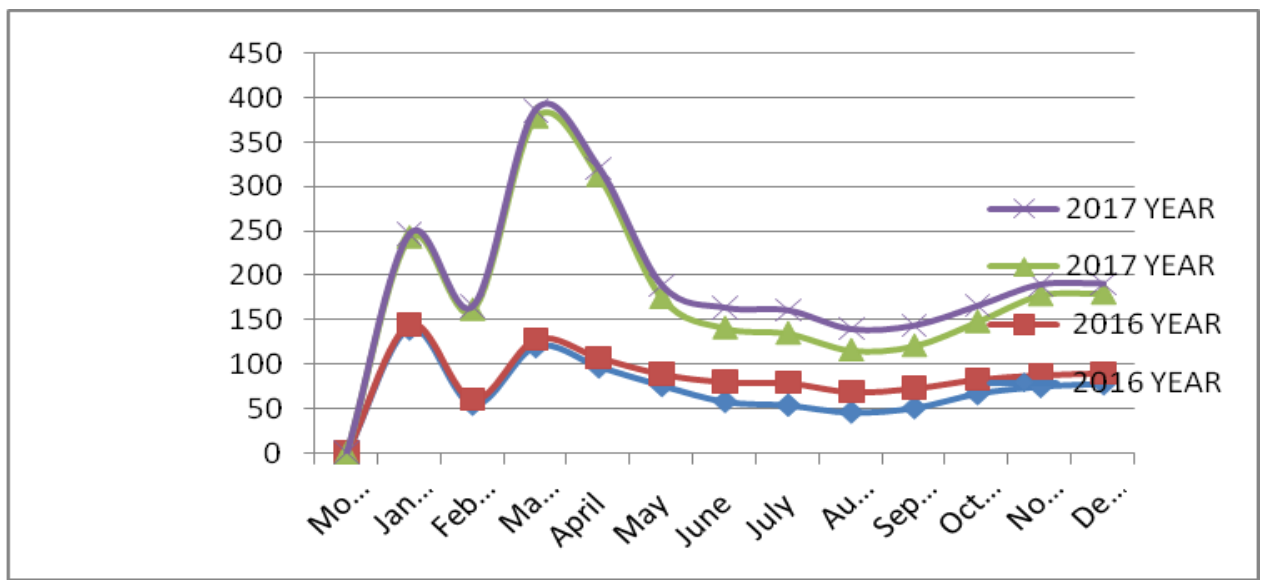

Fig.2 Effects of fertilizer Mg and Fe in the leaves of Cv. Shesh i Zi, grapevine 2016

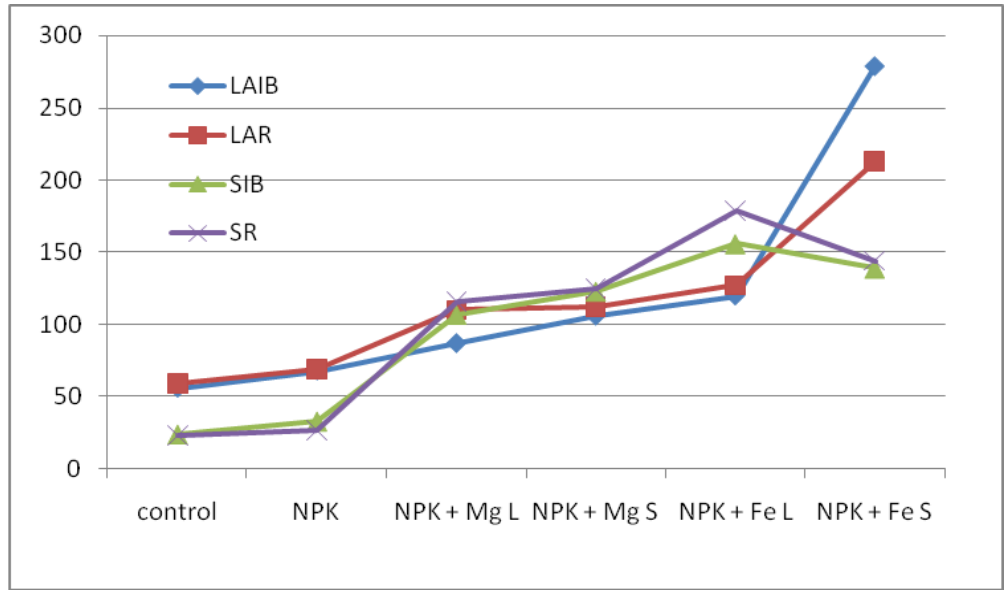

LAIB-Leaf area/Init berry; SIB-Shoots Initiat berry; LAR-Leaf area ripening; SR-Shots Ripening

Fig.3 Effects of fertilizer Mg and Fe in the leaves of Cv. Shesh i Zi, grapevine 2017

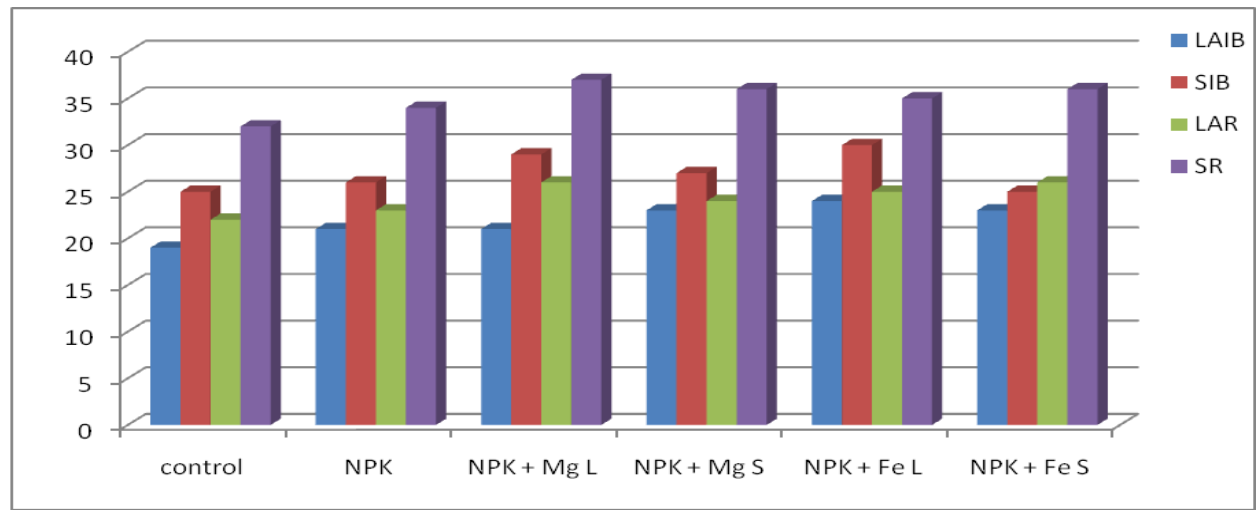

LAIB-Leaf area/Init berry; SIB-Shoots Initiat berry; LAR-Leaf area ripening; SR-Shots Ripening

Furthermore, the $\mathrm{Fe}$ concentration was reduced by $60 \%$ on both leaf surfaces and 
shoots (respectively 76-105 and 18-22 mg $\mathrm{kg}^{-1}$ ). In 2017, the Fe concentration of leaf surface was significantly increased by all fertilization treatments (average value of 76$96 \mathrm{mg} \mathrm{kg}^{-1}$ ) compared to controls (56 $\pm 8 \mathrm{mg}$ $\left.\mathrm{kg}^{-1}\right)$. In the first phase of the survey, a significant amount of the higher of the $\mathrm{Fe}$ were observed in the surface of the leaf and shoots when the same element was added leaf fertilization (treatment 5; $120 \pm 7$ and $124 \pm 2$ $\mathrm{mg} \mathrm{kg}^{-1}$ respectively) or in combination with $\mathrm{Mg}$ (Treatment 4: $106 \pm 6$ and $23 \pm 2 \mathrm{mg} \mathrm{kg}^{-1}$, respectively) (Table 4).

In both seasons, the $\mathrm{Zn}$ concentration in almost all cases was lower leaf surface (17 \pm 1 vs. $14 \pm 1 \mathrm{mg} \mathrm{kg}^{-1}$ in the berry phase and 19 \pm 2 vs. $22 \pm 4 \mathrm{mg} \mathrm{kg}^{-1}$ ripening times 2016 and 2017 respectively) and the shoots (27 - 3 versus $\pm 425 \mathrm{mg} \mathrm{kg}^{-1}$ in the berry phase and $52 \pm 2$ versus $32 \pm 5 \mathrm{mg} \mathrm{kg}^{-1}$ in the ripening time, respectively) at vineyards untreated and differences were also statistically confirmed (Table 5).

The concentration of $\mathrm{Zn}$ increased in time from the formation of berries to ripening all samples leaves. Furthermore, the content of $\mathrm{Zn}$ was increased to handle degein the vine or $\mathrm{Mg}$ or Fe alone or in combination (from 2.2 to 2.9 times versus 1.6-2.2 in 2016 and 2017, respectively) compared with the control vines (1.9 compared to 1.3 in 2016 and 2017) or in pots which are only adding $\mathrm{N}, \mathrm{P}$ and $\mathrm{K}(2.2$ versus 1.4 times in 2016 and 2017 respectively). During the ripening, $\mathrm{Zn}$ (zinc concentrations were statistically significantly higher in treatments T 3-8 (66-89 versus 64$77 \mathrm{mg} \mathrm{kg} 2016$ and 2017 respectively) compared to untreated control.

The results of the study carried out in Grori Sauk vineyards, showed that $\mathrm{K}$ element is an important and critical factor for a report that has with $\mathrm{Mg}$ element, reducing $\mathrm{Mg}$ concentration in the leaves of grape caused clorosis.
Due to the high ratio between $\mathrm{K}$ and $\mathrm{Mg}$ and antagonistic relations, application of leaf fertilization with $3 \% \quad \mathrm{MgSO}_{4}$ solution, has avoided this problematic.

Seeing variability in experimental conditions studied treatments in lidhje of $\mathrm{Mg}$ fertilizer resulted in the increase of $\mathrm{Zn}$ concentration in leaf surfaces and shoots.

Application of $\mathrm{Fe}$ and $\mathrm{Mg}$ stimulates absorption, so that the relationship between $\mathrm{Mg}, \mathrm{Fe}$ and $\mathrm{Zn}$ should be studied in more detail in order to determine the relative importance of both aspects.

\section{References}

Bergmann, W; (1992). Nutritional Disorders of Plants, Development, Analytical and Visual Diagnosis. Gustav Fischer Verlag, Jena, pp: 86-333

Diaz, I., Barrón, V., del Campillo, MC, Torrent, J., (2010). Testing the ability of vivianite to Prevent iron deficiency in pot-Grown grapevine. Sci. Hortica. 123, 464-468.

Edlira Kukali (2009), Study of agronomic indicators of association of grapevine with olive, Bulletin of Agricultural Sciences, No. 2, f. 47 - 52.

George, M.R. and K. Rice. (2016) Plant Growth and Development. Ecology and Management of Annual Rangelands. Davis, CA: Department of plant Science. Pgs. 73-95.

Kummer M.M., and M. C. Vasconcelos, (2001). "Soil nitrogen utilisation for growth and gas exchange by grapevines in response to nitrogen supply and rootstock." Aus. J. Grape Wine Res. 7: 2-11. 6

Lindsay Allen, and Bruno de Benoist, (2006); Guidelines on food fortification with micronutrients, 376, 3-17

Omar Dary, Richard Hurrell Maas E., and Moore D, (1968). Manganese 
absorption by excised barley roots. Plant Physiol. 43, 527- 530

Parsons, A.J., E. L. Leafe, B. Collett, and W. Stiles. (1983) Characteristics of leaf and canopy photosynthesis of continuously- grazed swards. Journal of Applied Ecology 20:117-126.

Ruben Geert van den Berg (2017), Introduction SPSS

\section{How to cite this article:}

Amelot Grori, Ariola Bici, Renata Kongoli and Edlira Kukali. 2018. Effects of Foliar Fertilizations in the Vitis vinifera L. Species. Int.J.Curr.Microbiol.App.Sci. 7(02): 1849-1856. doi: https://doi.org/10.20546/ijcmas.2018.702.222 